\title{
ČLANCI
}

Dr hab. ZDISLAV BJEGANJSKI, redovni profesor

Univerzitet Kazimira Velikog

Bidgošć, J. K. Hotkjeviča 30, Republika Poljska

zdzislawbieganski@interia.pl

Dr JOANA ŠČUTKOVSKA, docent

UDK 94:341.311(497.1)"1999"

$316.658(438)$

Univerzitet Kazimira Velikog

Bidgošć, J. K. Hotkjeviča 30, Republika Poljska

histukw@gmail.com

originalan naučni rad

primljeno: 29. decembar 2016.

prihvaćeno: 17. maj 2017.

\section{POLJSKO JAVNO MNJENJE O BOMBARDOVANJU JUGOSLAVIJE 1999. GODINE}

APSTRAKT: U članku se razmatra akcija NATO u Srbiji 1999. godine. U prvom planu su kontroverze u Poljskoj koje je ta akcija izazvala. Podrška intervenciji u poljskom društvu bila je visoka, ali se uporedo sa produžavanjem bombardovanja procenat njenih pristalica smanjivao. Polovina Poljaka je odobravala akciju (osobe desničarskih ili centrodesničarskih stavova). Neznatno manje je bilo protiv (pristalice levice). Rat NATO-a sa Jugoslavijom je postao tema brojnih poljskih publikacija u kojima su predstavljena različita mišljenja. Deo listova je bio naklonjen intervenciji (Gazeta Viborča), a drugi su prema njoj bili izrazito kritični (Tribuna, Nje, Điš, Misl Polska, Naša Polska, kao i Naš Đennjik). Autori ukazuju da su sećanja i refleksije o događajima koji su se odigrali 1999. u Jugoslaviji još živi u Poljskoj.

\section{KLJUČNE REČI: Poljska, Jugoslavija, NATO, štampa, Kosovo}

Posle okončanja Hladnog rata postojali su pokušaji da se ostvari ideja „sveta bez ratova" $i$ da se odustane od vojnog faktora u odnosima između država. ${ }^{1}$ Eskalacije brojnih konflikata, posebno posle raspada sovjetskog bloka, brzo su pokazale njenu neostvarljivost. ${ }^{2}$ U Evropi su porasle separatističke tendencije, a jedan od konflikata - srpsko-albanski za Kosovo - bio je povod otpočinjanju oružanih dejstava. Dan 24. mart 1999. upisan je u istoriji kao momenat izbijanja rata Severnoatlantskog pakta sa Saveznom Republikom Jugoslavijom (SRJ). Iz perspektive NATO-a bombardovanje

${ }^{1}$ Czynnik wojskowy $w$ środowisku międzynarodowym na przelomie XX i XXI wieku, urednici Łukasz Jureńczyk, Sławomir Sadowski, Marcin Jastrzębski, Jan Waskan (Bydgoszcz: Wydawnictwo Uniwersytetu Kazimierza Wielkiego, 2016), 9.

${ }^{2}$ Krzysztof Kubiak, „Poheroiczny Zachód wobec wyzwań militarnych pierwszych dekad XXI wieku“, u: Czynnik wojskowy w środowisku, 19. 
pod šifrom Allied Force, kojim je rukovodio američki general Vesli K. Klark, predstavljalo je humanitarnu akciju čiji je cilj prevashodno bio zaustavljanje etničkog čišćenja na Kosovu, o kome je inače javno mnjenje u zapadnom svetu opširno informisano. NATO je planirao tri faze vazdušne operacije, a pri tome je u početku smatrano da je dovoljno nekoliko dana demonstracije sile da bi se Slobodan Milošević prinudio da prihvati uslove Zapada. Na početku su bombardovani ključni elementi protivvazdušne odbrane. Kada se posle sedam dana vazdušnih napada pokazalo da je koncepcija „munjevitog rata“ propala, odlučeno je da se lista ciljeva proširi. Bombardovani su stacionarni i pokretni ciljevi, kao i strateški, a u trećoj fazi i izabrani elementi privredne strukture u samoj Srbiji. Pri tome, tragične greške i smrt civila nisu mogli biti izbegnuti. Istovremeno, na Kosovu je trajao građanski rat. Intervencija NATO-a je prvobitno doprinela eskalaciji srpsko-albanskih netrpeljivosti. Bez značaja nije bila ni saradnja Oslobodilačke vojske Kosova (UÇK) sa komandom Pakta. Problematika vojne intervencije u Jugoslaviji dominirala je na samitu NATO-a u Vašingtonu, sazvanom od 23. do 25. aprila povodom 50-godišnjice te organizacije. Odlučeno je da se vazdušni napadi nastave i razmotrena je mogućnost oružane akcije na kopnu. NATO bombardovanje Jugoslavije trajalo je do 10. juna 1999. godine. Okončano je pregovorima sa Beogradom čiji je rezultat bio sporazum i obustavljanje ratnih dejstava. Jugoslovenska vojska se povukla sa Kosova, a na taj prostor ušle su međunarodne snage bezbednosti KFOR (Kosovo Force). ${ }^{3}$

\section{Zvaničan stav Republike Poljske}

Odluka NATO o upotrebi oružanih snaga u cilju otklanjanja srpsko-albanske krize na Kosovu poklopila se sa stremljenjima Poljske ka članstvu u Paktu i Evropskoj uniji; dakle, iz poljske perspektive, došla je u ,veoma nepodesnom momentu“. 4 Stupanje Poljske u NATO 12. marta 1999. odigralo se u senci vojne intervencije Pakta u Jugoslaviji. Kako je primetio jedan od poljskih političara, ,vreme poljskog članstva u NATO-u odmah je postalo vreme probe naše savezničke verodostojnosti i sposobnosti shvatanja politike u globalnim kategorijama“. 5 To pitanje je nesumnjivo imalo uticaj na zvaničan stav vlade i pojedinih parlamentarnih grupa, među njima $\mathrm{i}$ opozicije.

Mada Poljska nije formalno učestvovala u donošenju odluke o operacijama na Balkanu i nije uzela učešća u vazdušnoj kampanji protiv Jugoslavije, zvanično je podržala vojnu operaciju koju su inicirale Sjedinjene Američke Države. ${ }^{6}$ Takođe,

${ }^{3}$ Maciej Kuczyński, Krwawiaca Europa. Konflikty zbrojne i punkty zapalne w latach 19902000. Tto historyczne i stan obecny (Warszawa: Dom Wydawniczy Bellona, 2001), 271-279; Danuta Gibas Krzak, Serbsko-albański konflikt o Kosowo w XX wieku. Uwarunkowania - przebieg konsekwencje (Toruń: Wydawnictwo Adam Marszałek, 2009), 195-199.

${ }^{4}$ Agnieszka Orzelska, Polityka zagraniczna Polski wobec wybranych kwestii spornych $w$ stosunkach transatlantyckich 1989-2004 (Warszawa: Instytut Studiów Politycznych PAN, 2011), 225.

${ }^{5}$ Sejm Rzeczypospolitej Polskiej. 3 kadencja, 47 posiedzenie, 1 dzień (8. 4. 1999). 4 punkt porządku dziennego: Informacja rządu o podstawowych kierunkach polityki zagranicznej Polski. Poseł Leszek Miller, http://orka2.sejm. gov. pl/Debata3.nsf/main/3F86F750 (pristupljeno 9. 10. 2016).

${ }^{6}$ Łukasz Jureńczyk, Polska w Sojuszu Pótnocnoatlantyckim. Wojsko Polskie w operacjach reagowania kryzysowego NATO (Bydgoszcz: Wydawnictwo Uniwersytetu Kazimierza Wielkiego, 2016), $170,181,205-206,339$. 
Poljska je podržala stav SAD o reviziji strateške koncepcije NATO-a na samitu te organizacije u aprilu 1999, izjašnjavajući se za vođenje operacija na Balkanu bez odobrenja Saveta bezbednosti OUN. ${ }^{7}$

$\mathrm{Na}$ dan početka intervencije poljski predsednik Aleksander Kvašnjevski je izdao saopštenje u kome je konstatovano: „Zbog pogoršavanja situacije na Kosovu koja preti izbijanjem otvorenog konflikta i njegovim nepredvidivim posledicama po ceo region, zbog patnji koje se nanose civilnom stanovništvu, vojna operacija NATO-a je opravdana. Preduzeta dejstva potiču iz više nužde i izražavam nadu da će doneti otrežnjenje i dovesti do uspostavljanja mira“. ${ }^{8}$ U skladu sa takvim stavom koji je proisticao iz članstva Poljske u NATO-u, Pakt se odlučio na vojnu intervenciju pošto su ,izneverila diplomatska sredstva koja su za cilj imala rešavanje krize i sprečavanje ugrožavanja mira i međunarodne bezbednosti u regionu“. Akcija NATO-a tretirana je kao nadovezivanje na ,ideju intervencije zbog humanitarnih razloga“. Prihvatajući načelo suvereniteta za jedno od fundamentalnih načela međunarodnog prava, kriza na Kosovu je viđena kao poseban slučaj s obzirom na ,zločinačku delatnost" vlade Slobodana Miloševića.'

Zvaničan stav Poljske o pitanju intervencije NATO-a u srpsko-albanski konflikt na Kosovu predstavio je ministar spoljnih poslova Bronjislav Geremek; u isto vreme to je učinio i predsedavajući Organizacije za evropsku bezbednost i saradnju (OEBS) na zasedanju poljskog Sejma 8. aprila 1999.

Naglašavajući generalno prijateljski odnos Poljaka prema Srbima, Geremek je kritikovao režim Slobodana Miloševića i vladu u Beogradu kao odgovorne za dramu albanskog življa na Kosovu. Negativno je ocenio velikosrpske ambicije tamošnjih političara i izrazio uverenje da ,politika koju vodi Beograd predstavlja neposrednu opasnost za osnovne vrednosti na kojima se temelji međunarodni poredak“. Kako je ministar konstatovao: „Osećaj nacionalnog ponosa koji su Poljaci uvek cenili i poštovali kod Srba danas je instrumentalizovala vlast $u$ Beogradu $-\mathrm{u}$ ime zločina, po cenu ljudskih nesreća. Verujem, ipak, da je to samo tragična epizoda u povesti bliske nam Srbije“. Miloševićeva vlada je, po njegovom mišljenju, snosila odgovornost za kršenje sporazuma i neispunjavanje obećanja o povlačenju srpskih trupa sa Kosova. U toj situaciji Poljska je izražavala solidarnost sa albanskim življem Kosova, „lišenim elementarnih ljudskih prava“, koji su „represivne jugoslovenske snage“ prinudile da napusti svoje domove. ${ }^{10}$

Marek Valdenberg, jedan od najpoznatijih i najcenjenijih istraživača odnosa na Balkanu, analizirajući ekspoze ministra Geremeka prebacio mu je ,jednostranost“ i ,jednoznačnost“". U govoru je, po Valdenbergovom mišljenju, izostalo nadoveziva-

\footnotetext{
${ }^{7}$ Ibid., 181.

${ }^{8}$ Kryzys w Kosowie - Decyzja NATO - Konferencja prasowa Prezydenta RP, www.prezydent. pl/aleksandra-kwasniewskiego/aktualnosci/rok-2000-i-starsze/ar (pristupljeno 9. 10. 2016).

${ }^{9}$ Odpowiedź Ministra Spraw Zagranicznych RP Bronisława Geremka na oświadczenie senatora Zbigniewa Gołąbka, złożone na 33. posiedzeniu Senatu („Diariusz Senatu RP“ nr 35), ww2.senat. $\mathrm{pl} / \mathrm{k} 4 / \mathrm{dok} / \mathrm{diar} / 39 / 3906$ (pristupljeno 9. 10. 2016).

${ }^{10}$ Sejm Rzeczypospolitej Polskiej. 3 kadencja, 47 posiedzenie, 1 dzień (8. 4. 1999). 4 punkt porządku dziennego: Informacja rządu o podstawowych kierunkach polityki zagranicznej Polski. Minister Spraw Zagranicznych Bronisław Geremek, http://orka2.sejm. gov. pl/Debata3.nsf/main/48BD8E19 (pristupljeno 9. 10. 2016).
} 
nje na najvažnija pitanja, a to su: pravne osnove intervencije i njene posledice, kao i razmatranje istorijskih uslovljenosti etničkog konflikta na Kosovu. ${ }^{11}$

O intervenciji NATO-a oglasili su se i predstavnici glavnih poljskih parlamentarnih klubova. ${ }^{12}$ Zvaničan stav Poljske podržala je Izborna akcija Solidarnost (AWS). ${ }^{13}$ Takođe, akciju je - u ime Saveza demokratske levice (SLD) - odobrio Lešek Miler ,zbog uverenja da u današnjoj Evropi i stoleću koje dolazi nijedna vlast ne može da se oseća ovlašćenom da primenjuje etničko čišćenje i represiju“. Ipak, angažovanje u ,krvavoj balkanskoj drami“ predstavlja poraz političara i diplomatije, konstatovao je Miler. ${ }^{14}$

Vojna intervencija NATO-a u Jugoslaviji podelila je poljsku političku scenu, na šta ukazuju ne samo različite reakcije na levici i desnici već i u okrilju iste partije. Zvanično, Poljska je ispoljavala solidarnost sa Paktom, ali su taj jednoglasan stav remetili unutrašnji sporovi. ${ }^{15}$ Balkanska kriza je podelila poljsku levicu. Zvaničan stav kluba SLD nisu podržali svi poslanici. Lider Poljske socijalističke partije (PPS, pripadala klubu SLD) Pjotr Ikonovič uputio je poljskoj diplomatiji apel da ,ne bude previše revnosna“ u podržavanju nametane optike: „Danas nisu progovorili samo topovi. Danas je pobedio način razmišljanja generala, generala koje pokreće vojnoindustrijski kompleks“. Ikonovič se pokazao kao predstavnik dela poljskog javnog mnjenja koje je bilo zabrinuto zbog eskalacije nasilja: „To što se dogodilo u Jugoslaviji - bombe na Kosovu, u Prištini i u Beogradu svedoči samo o jednom: da na probleme ne treba pucati, probleme treba rešavati političkim putem“. ${ }^{16} \mathrm{Na}$ protivljenje brojnih partijskih kolega naišla je i poseta Beogradu Pjotra Ikonoviča i još troje poslanika SLD: Pjotra Gađinovskog, Vita Majevskog i Izabele Sjerakovske koja je predsedavala poljsko-jugoslovenskom parlamentarnom grupom. Klub SLD zvanično nije ni podržao niti se protivio putu u Beograd; taj put je od samog početka izazivao kontroverze, a po mišljenju resora spoljnih poslova bio je ,nepreporučljiv““. ${ }^{17}$ Priliku da se obrazloži svrsishodnost posete predstavljalo je zajedničko zasedanje Komisije spoljnih poslova i Komisije narodne odbrane Sejma 5. maja 1999, posvećeno odnosu poljske politike prema situaciji na Balkanu. Sjerakovska je tom prilikom rekla: „Pos-

11 Marek Waldenberg, Rozbicie Jugosławii. Jugosłowiańskie lustro międzynarodowej polityki (Warszawa: Wydawnictwo Naukowe SCHOLAR, 2005), 308.

${ }_{12}$ Ibid., 308-311. Takođe: A. Orzelska, Polityka zagraniczna ..., 232-236.

${ }^{13}$ Sejm Rzeczypospolitej Polskiej. 3 kadencja, 47 posiedzenie, 1 dzień (8. 4. 1999). 4 punkt porządku dziennego: Informacja rządu o podstawowych kierunkach polityki zagranicznej Polski. Poseł Czesław Bielecki, http://orka2.sejm. gov. pl/Debata3.nsf/main/0CA9ED1A (pristupljeno 9. 10. 2016).

${ }^{14}$ Sejm Rzeczypospolitej Polskiej. 3 kadencja, 47 posiedzenie, 1 dzień (8. 4. 1999). 4 punkt porządku dziennego: Informacja rządu o podstawowych kierunkach polityki zagranicznej Polski. Poseł Leszek Miller, http://orka2.sejm. gov. pl/Debata3.nsf/main/3F86F750 (pristupljeno 9. 10. 2016).

${ }^{15}$ Mariusz Janicki, Magdalena Michalska, „Bomby i miny“, Polityka, br. 21, (1999).

${ }^{16}$ M. Waldenberg, Rozbicie Jugosławii, 308-309; Sejm Rzeczypospolitej Polskiej. 3 kadencja, 47 posiedzenie, 1 dzień (8. 4. 1999). 4 punkt porządku dziennego: Informacja rządu o podstawowych kierunkach polityki zagranicznej Polski. Poseł Piotr Ikonowicz, http://orka2.sejm.gov. pl/Debata3.nsf/main/2FCC18CF (pristupljeno 9. 10. 2016).

${ }^{17}$ M. Janicki, M. Michalska, op. cit.; „Posłowie SLD jadą do Belgradu“, http://archiwum. rp. pl/artykul/225337-Poslowie-SLD-jada-do-Belgradu. html, (pristupljeno 10. 11. 2016); ,Miloszević dzieli lewicę", Gazeta Wyborcza, br. 102, (1999). Sjerakovska je podvlačila da je u Jugoslaviju otputovala u atmosferi hajke koju su pravili poljski mediji i vladajuća koalicija. Apel redigovan na njenu inicijativu podržalo je 119 poslanika. Dziś, br. 7, (1999), 14-15. 
le otpočinjanja ratnih dejstava od strane NATO-a dobila sam poziv od Komisije spoljnih poslova skupštine Federativne Republike Jugoslavije. Poziv je bio veoma kratak: „Dođite. Hoćemo da razgovaramo sa vama“. Ako nas Jugosloveni pozivaju i hoće da razgovaraju sa nama, to je važno (...) nemamo želju da se čak ni slučajno sretnemo sa gospodinom Miloševićem, pošto putujemo na poziv parlamentaraca. $\mathrm{O}$ čemu ćemo da razgovaramo sa našim jugoslovenskim kolegama? O obustavljanju konflikta (...). Ako bi na neki skroman način glas poljskih parlamentaraca, među njima moj - ženski - mogao da spreči nesreću, vredi preduzeti takvu inicijativu. Za mene nema razlike da li plače srpsko, makedonsko ili albansko dete. Plače dete“ ${ }^{18} \mathrm{U}$ kontekstu angažovanja poslanika levice, treba dodati da je dva meseca posle početka bombardovanja, na inicijativu Izabele Sjerakovske i Pjotra Ikonoviča, grupa poslanika SLD i PSL podnela projekat rezolucije „U predmetu okončavanja rata u Jugoslaviji“. ${ }^{19}$ Zatim, 10. aprila 1999. poslanice SLD uputile su Apel ženama Evrope i Sjedinjenih Država koji je pozivao na obustavljanje bombardovanja i otpočinjanje mirovnih pregovora. ${ }^{20}$ Grupa od 61 poslanika SLD uputila je sličan apel predsedniku SAD Bilu Klintonu. Zalažući se za primenu mirovnih rešenja poslanici navode: „Niko ne sumnja da je najveća vojna sila na svetu u stanju da sa lica zemlje izbriše čitavu Jugoslaviju. Molimo Vas da to ne dokazujete““. ${ }^{21}$

O pitanju bombardovanja izjašnjavali su se i poslanici drugih klubova. Najpre je Jacek Soska, portparol Poljske narodne stranke (PSL), izdao saopštenje u kome je „kategorično“ zahtevao „prekidanje zverskih bombardovanja“, a kasnije je Marek Savicki, potpredsednik PSL, objavio da to nije stav partije već samog Soske. ${ }^{22}$ Votum separatum prema deklaraciji podrške za akciju NATO-a izneo je Jan Lopušanjski koji je napustio AWS i osnovao partiju protivnu NATO-u i EU pod nazivom Poljski sporazum. ${ }^{23}$ Rat NATO-Jugoslavija izazvao je emotivnu reakciju funkcionera Unije slobode (UW) koji su zvanično „osudili one koji u inostranstvu i Poljskoj istupaju protiv delovanja saveznika. Nezavisno od argumenata kojima se služe oni istupaju u odbrani genocida“. ${ }^{24}$ Osim toga, dok je rukovodstvo UW podržavalo NATO intervenciju, gotovo četvrtina njenih birača je imala drugačije mišljenje o tom pitanju. ${ }^{25}$

Koliko je nekim poslanicima bilo teško da prihvate moralne i političke premise odluke NATO-a, veće kontroverze nije izazivalo pitanje humanitarne pomoći u

${ }^{18}$ Posiedzenie połączonych Komisji Spraw Zagranicznych i Obrony Narodowej Sejmu RP, http://orka. sejm. gov. pl/Biuletyn. nsf/0/CFF6A58091A57C11C1256B730036B373 (pristupljeno 13. 11. 2016). Za vreme boravka u Beogradu članovima poljskog parlamenta su pokazani bombardovani objekti, među njima i zdanje kineske ambasade i Radio televizije Srbije. Sreli su se sa poglavarima pravoslavne i katoličke crkve u Srbiji - patrijarhom Pavlom i nadbiskupom Francom Perkom, a takođe i sa Poljacima koji žive u Beogradu. Trybuna, (13. 5. 1999).

${ }^{19}$ Dominika Wielowieyska, „Miloszević musi się wycofać“, Gazeta Wyborcza, br. 120, (1999).

${ }^{20}$ Trybuna, (11. 5. 1999).

${ }^{21}$ Trybuna, br. 89 (16. 4. 1999).

22 Jerzy Sławomir Mac, Anna Bogusz, „Barwy walki. Przeciwnicy NATO wszystkich krajów łączą się“, Wprost, br. 15, (1999).

${ }_{23}$ Partie $i$ koalicje polityczne III Rzeczypospolitej, (ur.) Krystyna Paszkiewicz (Wrocław: Wydawnictwo Uniwersytetu Wrocławskiego, 2000), 79-80.

${ }^{24}$ Bogusław Mazur, „Wojna o pokój“, Wprost, br. 18, (1999); Ryszard Holzer, „Emocje UW”, Gazeta Wyborcza, br. 97, (1999), 2.

${ }^{25}$ J. Sławomir Mac, A. Bogusz, op. cit. 
koju je poljska vlada odlučila da se uključi preko organizovanja humanitarnih transporta, kao i obezbeđujući u Poljskoj smeštaj za albanske izbeglice sa Kosova. U akciju pomoći uključile su se i nevladine organizacije (Poljska humanitarna akcija, Veliki orkestar praznične pomoći, Karitas Poljska, poljski Crveni krst) ${ }^{26}$ i organi lokalne samouprave. Prve izbeglice su primljene u Smoševu kod Varšave. ${ }^{27}$ Zahvaljujući Upravi grada Krakova i sejmika malopoljskog vojvodstva u selu Golkovice kod Starog Sonča pripremljeno je 300 mesta za prihvat albanskih izbeglica. Na krakovskom Glavnom trgu za njih je 21. maja 1999. organizovan dobrotvorni koncert pod pokroviteljstvom premijera Ježija Buzka i gradonačelnika Krakova Andžeja Golaša. ${ }^{28}$

Poljaci su odlučili da pomognu, uprkos propagandi nenaklonjenoj Srbima, i stanovnicima Kragujevca razorenog vojnim dejstvima NATO-a. ${ }^{29}$ Inicijativa je potekla od lokalnih vlasti i stanovnika bratskog grada Bidgošča. Lokalna štampa, između ostalog i Gazeta Pomorska, objavljivala je dosta informacija iz Jugoslavije. Već u toku bombardovanja je najavljeno da će posle prestanka neposredne opasnosti Bidgošč pružiti humanitarnu pomoć stanovnicima bratskog grada. Od aprila 1999. trajale su pripreme i prikupljanje pomoći među preduzećima i privatnim licima, a 8 . septembra 1999. krenuo je konvoj od tri kamiona sa 60 tona tovara. Na poziv gradonačelnika Kragujevca u posetu tom gradu uputili su se gradonačelnik Bidgošča Roman Jasjakjevič i predsedavajuća gradskog saveta Felicija Gvinćinjska. ${ }^{30}$

\section{Intervencija NATO-a u odabranim publicističkim tekstovima}

„Kaznena ekspedicija“ Severnoatlantskog pakta protiv Jugoslavije izazvala je žive reakcije u celom svetu, a posebno u državama koje su učestvovale u toj akciji. ${ }^{31}$ Napad NATO-a na Jugoslaviju je takođe izazvao znatne emocije i kontroverze u Poljskoj. Rat NATO-a sa Jugoslavijom je postao tema brojnih poljskih publikacija. Mada su saznanja ovdašnjih naučnika vezana za srpsko-albanski konflikt za Kosovo dosta bogata, većina istraživača se koncentrisala na njegovu istorijsko-političku uslovljenost i na analizu toka operacije Allied Force. Takođe, analizirani su i njeni medijski aspekti. Ipak, barem do sada, izostajala je publikacija posvećena isključivo reakcijama poljskog javnog mnjenja na ovo bombardovanje. Treba, međutim, naglasiti da

${ }^{26}$ Janusz Tomaszewski, „Globalna pomoc“, Wprost, br. 16, (1999); Magdalena Jarco, Marcin Klimkowski, „Serce Polski“, Wprost, br. 16, (1999); Jacek Szczęsny, Piotr Kudzia, „Wędrówka ludów“, Wprost, br. 16, (1999); Piotr Pytlakowski, Jowita Flankowska, „Przystanek na żądanie“, Polityka, br. 17, (1999).

${ }^{27}$ Wojciech Staszewski, Monika Słowakiewicz, „Spokojne niebo nad Smoszewem“, Gazeta Wyborcza, br. 85, (1999).

${ }^{28}$ Piotr Pytlakowski, „Małe Bałkany“, Polityka, br. 24, (1999); Maciej Łuczak, „Koncert dla Kosowa“, Wprost, br. 21, (1999).

29 Przemysław Biegański, „Współpraca miast partnerskich na przykładzie Bydgoszczy i Kragujevca“, u: Polska i Jugosławia w stosunkach międzynarodowych po II wojnie światowej, Zbornik radova, urednici Momčilo Pavlović i Andrzej Zaćmiński (Bydgoszcz: Wydawnictwo Uniwersytetu Kazimierza Wielkiego, 2014), 379.

${ }^{30}$ Gazeta Pomorska, br. 209, (7. 9. 1999).

${ }^{31}$ Antoni Czubiński, Historia powszechna XX wieku (Poznań: Wydawnictwo Poznańskie, 2003), 749. 
su bitan doprinos istraživanjima na tom polju dali Marek Valdenberg i Lukaš Šurminjski. ${ }^{32}$

Interesovanje poljske javnosti za situaciju na Balkanu tokom NATO bombardovanja bilo je znatno. Konflikt je privukao pažnju izrazite većine Poljaka. Na osnovu ispitivanja javnog mnjenja koje je nekoliko puta izvršio Centar za ispitivanje javnog mnjenja (OBOP) ${ }^{33}$ proisticalo je da se poljsko društvo dobro orijentisalo u unutrašnjim pitanjima Jugoslavije. U Poljskoj su redovno praćeni događaji na Balkanu, uz razmatranje mogućih scenarija rešavanja situacije i - sa protokom vremena - posledica rata na Kosovo ne samo u kontekstu humanitarne krize, već uopšte jugoslovenske istorije i identiteta. ${ }^{34}$

Većina časopisa i novina je objavljivala redakcijske uvodnike i aktuelne informacije sa Balkana, a prenošeni su i tekstovi iz evropskih i američkih listova važnih za formiranje javnog mnjenja koji su izražavali širok spektar gledišta (najviše tekstova iz zapadne štampe donosio je nedeljnik Forum, koji inače daje pregled svetske štampe). Rezultati ispitivanja su pokazivali prilično veliku polarizaciju pogleda, a takođe i održavanje čak do kraja operacije NATO-a skoro nepromenjenih ocena o pitanju njene opravdanosti. U ispitivanju koje je tokom 16-21. juna 1999. izvršio CBOS $48 \%$ ispitanika je podržavalo intervenciju NATO-a u Jugoslaviji; istovremeno je porasla podrška članstvu Poljske u NATO-u. ${ }^{35}$

U publikacijama koje su sistematski izlazile tokom bombardovanja analizirana je istorijska i kulturna uslovljenost srpsko-albanskog konflikta na Kosovu, njegova eskalacija i međunarodne reakcije. Ovog puta, suprotno prvoj polovini devedesetih godina, to je bio i ,naš konflikt“ ${ }^{36}$ „Skoro dva meseca NATO bombarduje Jugoslaviju. I to je takođe naš rat, mada poljske bombe i rakete ne padaju na 'tvrde' i 'meke' ciljeve u Srbiji ili na Kosovu. Statiramo u drami koja pred našim očima menja lice Evrope i, možda, i sveta، ${ }^{\text {37 }}$ - pisao je Adam Kšeminjski o konfliktu koji je u Poljskoj

32 Videti: Magdalena Pioruńska, Przyczyny rozpadu Jugosławii w latach 90. XX wieku (Poznań: Wydawnictwo Naukowe Scriptorum, 2010); Izabela Rycerska, Rozpad Jugosławii. Przyczyny i przebieg (Kielce: Wyd. Akademii Świętokrzyskiej, 2003); Maciej Kuczyński, Bałkańska pożoga: wojny $i$ konflikty na Batkanach $w$ latach 1981-1999 (Warszawa: Biuro Prasy i Informacji Ministerstwa Obrony Narodowej, 1999); Maciej Kuczyński, Marian Ray-Ciemięga, Bałkański syndrom: konflikty zbrojne $w$ bytej Jugosławii 1991-1999 $i$ wojna $w$ Kosowie: udziat wielonarodowych sit pokojowych NATO w utrzymaniu pokoju na Batkanach 1993-2000 (Warszawa: Dom Wydawniczy Elipsa, 2000).

${ }_{33}$ Prvo ispitivanje poljskog javnog mnjenja o problemima vezanim za rat na Balkanu OBOP je izvršio sedam dana posle početka vazdušnih napada NATO na Jugoslaviju. „NATO - Jugosławia: Polacy o konflikcie zbrojnym“, http://tnsglobal. pl/archiv_files/048-99.pdf (pristupljeno 5. 11. 2016). Uporediti: kominikei Centra za ispitivanje javnog mnjenja (CBOS) - Polacy o interwencji NATO w Jugosławii. Komunikat $\mathrm{z}$ badań. Warszawa, kwiecień' 99, http://www.cbos. pl/SPISKOM. POL/1999/K_053_99.PDF, (pristupljeno 17. 10. 2016).

34 Andrzej Szoszkiewicz, „Serbska ruletka“, Wprost, br. 15, (1999); Juliusz Urbanowicz, „Strażnik świata“, Wprost, br. 16, (1999); Andrzej Nowosad, „Wojny po wojnie“, Polityka, br. 25, (1999); Artur Górski, „Lot mydlanej bańki“, Polityka, br. 26, (1999); isti, „Krajobraz po bitwie“, Polityka, br. 27, (1999); Miłada Jędrysik, „Uzbrojone prawa człowieka“, Gazeta Wyborcza, br. 154, (1999), 10.

${ }^{35}$ Gazeta Pomorska, br. 168, (21. 6. 1999).

${ }^{36}$ Piotr Nowina - Konopka, „Świąteczny przekładaniec“, Wprost, br. 15, (1999).

${ }^{37}$ Adam Krzemiński, „Bić czy nie bić“, Polityka, br. 20, (1999). 
pokrenuo brojne političke, moralne i intelektualne debate usmerene na traženje kompleksnog rešenja balkanskog problema.

Štampa je, slično političkim partijama, iznosila različita mišljenja o intervenciji NATO-a. Deo listova joj je bio naklonjen (npr. Gazeta Viborča), a drugi su prema njoj bili izrazito kritični (Tribuna). Malobrojni su uspeli da sačuvaju uravnotežen odnos prema angažovanju NATO-a na Balkanu. Prema poznavaocu medija Lukašu Šurminjskom, ,zdravu novinarsku distancu“ trudile su se da sačuvaju Žečpospolita i Politika. U tu grupu se može ubrojati i Vprost. Među protivnicima intervencije našli su se Tribuna, Nje, Điš, Misl Polska, Naša Polska, kao i Naš Đennjik - listovi blisko povezani sa radikalnim političkim grupacijama, podjednako s leve kao i s desne strane političke scene, čiji su predstavnici ranije iznosili primedbe prema prijemu Poljske u NATO. ${ }^{38}$ Pokušaji generalizacije stavova pojedinih listova su se vremenom pokazali nepouzdanim. U Politici su, ilustracije radi, objavljivali pristalice intervencije kao i njeni protivnici (Ludvik Stoma). Tigodnjik Solidarnošć je u istom broju objavio tekst Andžeja Gelberga naslovljen „Nie wolno zatrzymywać się w pół drogi““ („Ne sme se zadržavati na pola puta“) koji je naglašavao tesnu vezu između vojnih dejstava NATO-a sa neophodnošću odbrane ljudskih prava, kao i tekst Valdemara Lisjaka „Protestuję“ („Protestujem“) u kojem autor piše: „Protestujem protiv banditskog napada vojske Zapada na suverenu jugoslovensku državu - napada čiji je cilj otimanje velikog dela teritorije te države“. 39

U vezi sa kosovskom krizom postavljena su brojna pitanja: Da li se u multietničkoj i multikulturalnoj Evropi može prihvatiti unutrašnja invazija vojske zemlje čija vlada ne ume da osigura autonomiju jedne od svojih provincija? ${ }^{40}$; Kakve zakonske osnove treba da ima vojna intervencija preduzeta $\mathrm{u}$ ime humanitarnih vrednosti $\mathrm{i}$ da li prirodno pravo može da bude osnova političke delatnosti?; „Da li je život Kurda i Ruanđanina manje vredan jer su imali peh da se rode van Evrope?“" ${ }^{41}$ Kako se akcija Pakta produžavala, čak i među osobama koje su ju podržavale počele su se pojavljivati sumnje. Pitano je: „Da li je akcija NATO-a bila neophodna?“; ${ }^{42}$ „Koliko će još vremena i žrtava odneti?““;3 „Da li je Kosovo poslednji čin jugoslovenske tragedije? Ili će se pak u obližnjoj Makedoniji uskoro ponoviti scenario poznat iz Bosne i Hercegovine? Koliko dugo će NATO bombardovati Jugoslaviju i da li će napadi biti vršeni samo iz vazduha?“; ${ }^{4}$, „Ko će platiti Srbima za višemilijardske štete nanete u toku nekoliko nedelja 's laserskom preciznošću' višemilijardskim bombama bacanim iz višemilijardskih aviona na imetak naroda pretvaran u ruševine: na fabrike, rudnike, rafinerije, mostove, autoputeve, zgrade i televizijske stanice?“. ${ }^{45}$ Pisano je o teško-

38 J. Sławomir Mac, A. Bogusz, op. cit. Više o tome: Łukasz Szurmiński, Mechanizmy propagandy. Wizerunek konfliktu kosowskiego w publicystyce (Warszawa: Aspra, 2008), 225-236, 246.

39 Andrzej Gelberg, Waldemar Łysiak, „Pojedynek: czy interwencja NATO jest słuszna?“, Tygodnik Solidarność, br. 14, (2. 4. 1999), 3.

${ }^{40}$ Czesław Bielecki, „Obrona Europy“, Wprost, br. 14, (1999).

${ }^{41}$ Jarosław Giziński, ,Wojna o pokój“", Wprost, br. 14, (1999).

${ }^{42}$ Marek Ostrowski, Jerzy Baczyński, „Święto na później“, Polityka, br. 17, (1999).

${ }^{43}$ Piotr Moszyński, ,To nie żarty“, Wprost, br. 16, (1999).

${ }^{44}$ Andrzej Nowosad, „Bałkańskie domino“, Polityka, br. 15, (1999).

${ }^{45}$ Walery Amiel, „Leczenie bombami“, Wprost, br. 19, (1999). 
ćama u definisanju prirode balkanskih događaja: „Da li je to rat ili intervencija, ili možda neka druga, nedefinisana operacija?“, početkom maja 1999. odgovor na ovo pitanje tražio je Pjotr Novina-Konopka. ${ }^{46}$

Razmatrano je da li je intervencija NATO-a mogla uspešno rešiti komplikovane etničke probleme na Balkanu, ${ }^{47}$ kao i ,Zašto Evropljani sopstvenim političkim, privrednim i diplomatskim snagama ne umeju da izađu na kraj sa svojim problemima?“. ${ }^{48}$ Ukazivano je na nužnost da javno mnjenje u Poljskoj podrži akciju NATO, što ne treba da isključuje javnu diskusiju. Često je citiran stav Zbignjeva Bžežinjskog, uticajnog američkog političara poljskog porekla, koji je podvlačio potrebu vođenja vazdušne kampanje sve do postizanja nameravanih ciljeva: „NATO će pomoći Miloševiću da donese odluku“.

Razmatrajući balkansku dramu često se pozivalo na poljsko iskustvo. Publicista i političar Česlav Bjelecki (tada poslanik AWS) pisao je: „Poljska je već preživela iskustvo unutrašnje agresije. To je bilo ratno stanje. Za potrebe švajcarske štampe nazvao sam ga crvenim aparthejdom. Crveni - koji su bili u manjini - tada su ugnjetavali bele, tačnije crveno-bele. Prošlo je dosta godina i beogradski režim dalje ugnjetava kosovske Albance koji su većina na tom parčetu zemlje. To što Srbi smatraju Kosovo svojim matičnom zemljom - kolevkom naroda - ne daje im nikakvo pravo za progone Kosovara koji žele autonomiju“" ${ }^{50}$

Ježi Surdikovski, jedan od protivnika vojne akcije Pakta, konstatovao je: „Zaboravilo se na psihologiju malih, iskompleksiranih naroda koje je istorija teško iskušavala, kao makar i Poljake. Da je predsednik Roland Regan u odmazdi za uvođenje u decembru 1981. ratnog stanja počeo da bombarduje Varšavu, postigao bi samo ujedinjenje naroda oko generala Jaruzelskog i priznavanje „Solidarnosti“ za zločinačku organizaciju“. Prema Surdikovskom, zapadnim stratezima je „nedostajao razum i umeće predviđanja“. O tome da se njihova taktika pokazala pogrešnom iznad svega svedoči činjenica da se položaj stanovnika Kosova pogoršao, a Milošević dobio „,izvanredan poklon: ujedinjenje naroda oko diktatora protiv spoljnog neprijatelja“. 51

Poljsko javno mnjenje se živo interesovalo za život i delatnost Slobodana Miloševića - koji je ponekad nazivan ,predsednikom rata“ - i njegovih saradnika. Beogradski režim je kritikovan i prebacivano mu je manipulisanje društvom. Kao što je primetio Lukaš Šurminjski, Miloševića je bez ikakvih skrupula posebno napadala Gazeta Viborča koristeći u tu svrhu emotivan rečnik. ${ }^{52}$ Istican je problem Miloševi-

\footnotetext{
${ }^{46}$ Piotr Nowina-Konopka, „Pieczeń z bizona“, Wprost, br. 18, (1999).

${ }^{47}$ Krzysztof Kęciek, ,Serbska pułapka?: interwencja NATO nie rozwiązała żadnego problemu“, Przegląd Tygodniowy, br. 13, (1999), 4-5; Jerzy Jedlicki, „Dobre chęci, skutki opłakane: wojna NATO z Jugosławią", Gazeta Wyborcza, br. 100 (1999), 6-7.

${ }^{48}$ Sejm Rzeczypospolitej Polskiej. 3 kadencja, 47 posiedzenie, 1 dzień (8. 4. 1999). 4 punkt porządku dziennego: Informacja rządu o podstawowych kierunkach polityki zagranicznej Polski. Poseł Piotr Ikonowicz, http://orka2.sejm. gov. pl/Debata3.nsf/main/2FCC18CF, (pristupljeno 9. 10. 2016).

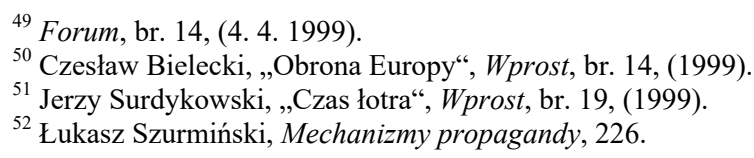


ćeve odgovornosti za „zločine koje su počinili Srbi“ i praćene su okolnosti podizanja tužbe protiv njega u Međunarodnom krivičnom sudu za bivšu Jugoslaviju u Hagu. ${ }^{53}$

Po mišljenju većine Poljaka najodgovornija za izbijanje rata bila je vlada Jugoslavije, mada je uočavana i krivica Albanaca sa Kosova i vlada država NATO-a. Ipak, nisu svi bili uvereni da su sva sredstva mirnog rešavanja srpsko-albanskog spora za Kosovo bila iscrpljena. ${ }^{54}$ Takođe, u Poljskoj nisu svi verovali propagandi koja je govorila da Oslobodilačka vojska Kosova nije činila zločine, praveći se da je UÇK „armija anđela““. ${ }^{55}$ Analizirani su njena struktura i delovanje, ${ }^{56}$ uz obraćanje pažnje na diplomatski talenat vođe UÇK Hašima Tačija, „moćnog čoveka“ Kosova. Prema mišljenju poljskih posmatrača: „Tačijevo političko remek-delo je bilo uveravanje Zapada da bombarduje Jugoslaviju. U Rambujeu je uspeo da celu krivicu za krizu na Kosovu prebaci na Miloševića i ućutka glasove koji su podsećali na to da su etničko čišćenje na Kosovu, u suštini, otpočeli Albanci““. ${ }^{57}$

Odnos prema NATO intervenciji u Jugoslaviji izazvao je oštre sporove među publicistima koji su predstavljali tadašnju vladajuću koaliciju i deo opozicije, prosto „isturanje najtežih topova“ zaključno sa optužbama za izdaju nacionalnih interesa. Ježi Marek Novakovski i „Tigodnjiku Solidarnošćc tvrdili su da su na stranicama Tribune i Nje izlazili tekstovi koji su nanosili štetu poljskim državnim interesima; u tim tekstovima NATO je predstavljan kao agresor koji realizuje interese Sjedinjenih Američkih Država. ${ }^{58}$ Autori tekstova u teorijskom mesečniku postkomunističke levice Điš (Mječislav Rakovski, Joana Ravik, Vladislav Baka i drugi) principijelno su negirali pravo upotrebe sile prema Jugoslaviji, uočavajući razne povode za vojno angažovanje Zapada, često skrivane pred međunarodnim javnim mnjenjem (npr. uloga vojne industrije u SAD). Istovremeno je primećeno da se kritičari bombardovanja Jugoslavije nalaze u teškoj situaciji. ${ }^{59}$ Pristalice jednoznačno proameričkog stava o pitanju intervencije pozivale su se na povoljna ispitivanja javnog mnjenja u pogledu odluke o napadu NATO-a. Poljska strana, po njihovom mišljenju, koja direktno ne učestvuje u operaciji niti je finansira treba da joj pruži „barem jasnu podršku“. ${ }^{60}$

List koje je ratu u Jugoslaviji posvećivao izuzetno mnogo prostora bila je Tribuna koja je izražavala gledišta postkomunističke poljske Socijaldemokratije (od 15. aprila 1999. koalicije Savez demokratske levice - SLD). U to vreme SLD je zauzimao najviše mesto u ispitivanjima podrške političkim partijama u Poljskoj. Mada su rukovodioci SLD zvanično izražavali podršku akciji NATO, na stranicama novina povezanih sa levicom generalno se odlučno protivilo intervenciji. Podvlačeno je

${ }^{53}$ Maria Graczyk, Andrzej Szoszkiewicz, „Prezydent WOJNY“, Wprost, br. 16, (1999); Marek Popowski, „Pistolet w kolebce“, Wprost, br. 16, (1999); Andrzej Szoszkiewicz, Maciej Łuczak, „Trybunał sumienia“, Wprost, br. 18, (1999); Artur Górski, „Wańka - wstańka“, Polityka, br. 42, (1999); A. Mandalian, „Niepoprawność pamięci“, Gazeta Wyborcza, br. 261, (1999), 15.

${ }^{54}$ „NATO - Jugosławia: Polacy o konflikcie zbrojnym“, http://tnsglobal. pl/archiv_files/04899.pdf (pristupljeno 5. 11. 2016).

${ }^{55}$ Walery Amiel, „Leczenie bombami“", Wprost, br. 19, (1999).

${ }^{56}$ Jacek Pałasiński, „Wojsko z cienia“, Wprost, br. 23, (1999).

${ }^{57}$ Jacek Pałasiński, „Strategia Węża“, Wprost, br. 28, (1999).

58 „Głos agentury”, Nie, br. 16, (22. 4. 1999).

${ }^{59}$ "Dziś, br. 6, (1999).

${ }^{60}$ Forum, br. 14, (4. 4. 1999), redakcijski uvodnik. 
selektivno tretiranje ljudskih prava od strane američkih i evropskih političara, ukazivano je na izostanak mandata OUN za vojnu akciju u Jugoslaviji, pisano je „o dve strane medalje na Kosovu“, objavljivani su članci iz svetske štampe koji dovode u sumnju smisao bombardovanja civilnih objekata u Srbiji, prenošene su informacije o izrazima simpatije i saosećanja Poljaka sa srpskim stanovništvom, objavljivani intervjui sa srpskim političarima (npr. ambasadorom Jugoslavije u Poljskoj Zoranom Novakovićem), ${ }^{61}$ ali pre svega neprekidno je informisano o tragičnim posledicama bombardovanja civilnih ciljeva koja su povećavala tragediju ljudi na Kosovu. Urednik Tribune Januš Rolicki je to sažeo u sledećem iskazu: „Stidim se što moja Otadžbina, htela ne htela, nastupa u ulozi agresora"“. ${ }^{62}$

\section{Stav poznatih javnih ličnosti - Tadeuša Mazovjeckog, Leha Valense i Mareka Edelmana}

Podrška intervenciji NATO-a u poljskom društvu bila je visoka, mada se produžavanjem bombardovanja procenat njenih pristalica smanjivao. Polovina Poljaka je odobravala akciju i to su najčešće bile osobe desničarskih ili centrodesničarskih pogleda. Neznatno manje je bilo protiv. Intervenciju Pakta, u većini slučajeva, nisu podržavale pristalice levice. U obe grupe su, ipak, dominirale osobe koje su mišljenje izražavale na umeren način (,,pre da“, ,,pre ne“). ${ }^{63}$

Formulišući svoje stavove brojni Poljaci su uzimali u obzir mišljenja poznatih ličnosti - autoriteta kao što su Tadeuš Mazovjecki, Marek Edelman ili Leh Valensa, pri čemu su se skoro svi pozivali na reči pape Jovana Pavla II koji je više puta apelovao na političare da prekinu krvoproliće na Balkanu. Prema Tadeušu Mazovjeckom, specijalnom izaslaniku Komisije za ljudska prava OUN na teritoriji bivše Jugoslavije u razdoblju 1992-1995, intervencija NATO-a je bila nužnost. Mazovjecki nije imao bilo kakve sumnje u njenu opravdanost, pošto ,predugo se mirilo sa mišlju da će se balkanski problem 'nekako' rešiti sam“. Nezavisno od počinjenih grešaka stalo se „na kraj nemoći sveta prema jugoslovenskom konfliktu“. ${ }^{64}$ Mazovjecki je više puta u intervjuima pokazao saosećanje sa ugnjetavanim Albancima sa Kosova, a takođe i sa Srbima čije domove je NATO bombardovao, jer ,svaki bol, svaka smrt je podjednako strašna“. ${ }^{65}$ Delovanja NATO-a u Jugoslaviji je odlučno podržao Marek Edelman, jedan od legendarnih vođa ustanka u varšavskom getu 1943, a u naznačenom periodu funkcioner Unije slobode. Edelman je ocenio da je odluka članica NATO o vazdušnim napadima na Kosovu preloman trenutak u svetskoj povesti, pošto je rat prvi put objavljen radi odbrane ljudskih prava, a ne radi težnje za proširenjem teritorija ili

${ }^{61}$ Trybuna, br. 85 (12. 4. 1999).

${ }^{62}$ Trybuna, br. 72 (26. 4. 1999).

${ }^{63}$ NATO - Jugosławia: Polacy o konflikcie zbrojnym“, http://tnsglobal. pl/archiv_files/048-99 (pristupljeno 5. 11. 2016); „Kosowo - wojna w mediach i w opinii publicznej“, http://tnsglobal. pl/archiv files/068-99 (pristupljeno 5. 11. 2016).

${ }^{64}$ Ryszard Bilski, „Wojny jugosłowiańskie. Rozmowa z Tadeuszem Mazowieckim“, u: Kocioł batkański, 417-420.

${ }^{65}$ Iza Wodzińska, „Każdy ból, każda śmierć. Rozmowa z Tadeuszem Mazowieckim, byłym specjalnym sprawozdawcą ONZ do spraw przestrzegania praw człowieka w Jugosławii“, Gazeta Pomorska, (9. 4. 1999), 2. 
osvajanjem sirovina. U specijalnom pismu predsednicima Bilu Klintonu i Žaku Širaku, premijeru Toniju Bleru, kancelaru Gerhardu Šrederu, generalnom sekretaru NATO Havijeru Solani i svim liderima NATO država, apelovao je da se na Kosovo upute kopnene snage. „Mir na Balkanu može da zavede samo kopnena armija (...). Znam kako je za one koji šalju vojnike u rat bolna svest da oni mogu da poginu. Ali takođe znam, kao svi iz mog pokolenja, da sloboda ima i mora da ima svoju cenu“, tvrdio je Edelman. ${ }^{66}$ Za iznuđivanje ustupaka od Miloševića izjašnjavao se i poznati poljski pisac Stanislav Lem. ${ }^{67}$

Leh Valensa je odlučno osudio akciju Pakta prebacujući Poljskoj nedostatak kritičnosti prema NATO-u. Smatrajući probleme vezane za rat u Jugoslaviji „,suviše važnim da bi bili prekrivani ćutanjem“", ${ }^{68}$ posvetio im je nekoliko uzastopnih feljtona u nedeljniku Vprost. U jednom od njih Valensa piše: „Bombe NATO-a mi se ne čine dobrom idejom. Naravno, budući da smo novopečeni član pakta moramo biti solidarni sa njegovim odlukama (...). Ipak, solidarnost ne treba da prikriva razum i da oslobađa od kritike (...). To su razlozi (nemoralnost, nezakonitost i neefikasnost) zbog kojih mi se to ne sviđa“. ${ }^{69}$ Obrazlažući svoj stav pre svega sumnjama moralne prirode, uporedio je bombardovanje $\mathrm{u}$ ime ljudskih prava sa proterivanjem đavola Belzebubom. Uz to, akcija NATO-a izazvala je kod Valense rezerve pravne i vojne prirode. Po mišljenju nobelovca najbolje rešenje konflikta bili bi pregovori. ${ }^{70}$ Vođen takvim ubeđenjem uputio je obema stranama pismo sa ponudom za posredovanje, kao i posebno pismo dobitnicima Nobelove nagrade za mir sledeće sadržine:

„Dragi dobitniče Nobelove nagrade za mir i dragi kolego,

Duboko sam uveren da se prema Nobelovoj nagradi odnosite - kao i ja - ne samo kao prema krunisanju delatnosti, ali takođe (a možda pre svega) kao obavezi. Ako se bilo gde vodi rat to je istovremeno izazov nama, laureatima. Sada sam uznemiren situacijom na Balkanu. Milioni ljudi gube svoje domove i imetak, hiljade gube živote, tone eksplozivnog materijala padaju na gradove i fabrike. Mi, ljudi mira, dužni smo da ponudimo naše posredovanje i stanemo na kraj pogibiji i nesreći naroda. Pozivam Vas da učestvujete u komitetu Nobelovci za mir na Balkanu čiji cilj će biti pružanje ruke obema stranama konflikta i ubrzanje njegovog kraja. S prijateljskim pozdravom, Leh Valensa“". 71

Po Valensinom mišljenju ostvarenje mira na Balkanu će biti moguće ako budu ispunjena tri „ne“: „ne“ etničkom čišćenju, proterivanju i kršenju ljudskih prava,

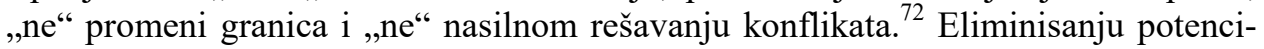
jalnih polja konflikta može doprineti pravilno ocenjivanje verske identifikacije kao političkog faktora. ${ }^{73} \mathrm{U}$ jednom od feljtona Leh Valensa je izrazio razočaranost zbog

${ }^{66}$ „Apel Marka Edelmana“, Gazeta Wyborcza, br. 79, (1999), 2; Joanna Szczęsna, „I już nic nie było jak przedtem. Rozmowa z Markiem Edelmanem“, Magazyn, dodatek Gazety Wyborczej, br. 94, (1999), 32; Bogusław Mazur, „Wojna o pokój“, Wprost, br. 18, (1999).

\footnotetext{
${ }^{67}$ Trybuna, br. 72 (26. 3. 1999).

${ }^{68}$ Lech Wałęsa, ,Teraz o czasie“", Wprost, br. 19, (1999).

${ }^{69}$ Lech Wałęsa, „Bazie i bomby“, Wprost, br. 15, (1999).

${ }^{70}$ Isto.

${ }^{71}$ Lech Wałęsa, „Zawsze się można dogadać“, Wprost, br. 16, (1999).

72 Isto.

${ }^{73}$ Lech Wałęsa, ,Okno i co za nim“, Wprost, br. 2, (1999).
} 
odluka samita NATO-a u Vašingtonu rezimirajući na sledeći način: „Kada mudri gremijumi diskutuju o embargu na tehnologiju, umiru ljudi““. ${ }^{74}$ Balkanska drama je, po njegovom mišljenju, pokazala potrebu temeljnih promena u funkcionisanju međunarodnih organizacija. ${ }^{75}$ Za Leha Valensu kraj NATO bombardovanja u Jugoslaviji nije značio da će na tom prostoru zavladati mir. U feljtonu objavljenom 4. jula 1999. on izražava svoja strahovanja: „Da li će se, braneći Albance od čistki, izazvati čistke uperene protiv Srba? Već sada se srećemo sa masovnim srpskim egzodusom. Da li će snage Severnoatlantskog pakta umeti da ih štite? Da li će umeti da drže mržnju u pokornosti - ostaje da se nadamo“. ${ }^{76}$

\section{Egzodus Albanaca sa Kosova i svakodnevni život u bombardovanoj Jugoslaviji}

Pažnju Poljaka privukao je i egzodus Albanaca sa Kosova. Mediji su pisali o etničkom čišćenju koje je vršio režim Slobodana Miloševića, ${ }^{77}$ otežavajući Poljacima pristup informacijama o oblastima uništenim bombardovanjem. „Ne znam kakve su prave razmere razaranja u Srbiji, jer te vesti naša televizija skoro ne prenosi zaklanjajući se time da ne zna. A možda neće da zna?", pisao je Tomaš Raček sugerišući učešće sredstva javnog informisanja u kreiranju slike jugoslovenske ratne stvarnosti. Ne podleže sumnji ocena da su sredstva masovnog informisanja odigrala značajnu ulogu u konfliktu. U poljskoj stručnoj literaturi ocenjuje se da ona nisu bila samo „sredstvo za 'proizvodnju' odobravanja javnog mnjenja za rat““, ${ }^{78}$ već da su ,predano pozivala u njega“" 79 Mada su mnogi Poljaci prihvatili medijsku ratnu propagandu, nisu joj svi podlegli. Publicista Tomaš Raček ocenjuje: „Od kada smo ušli u NATO i od kada je izbio rat u Jugoslaviji imam sve nametljiviji utisak da je televizija opet postala podređena propagandi (...). U balkanskom konfliktu loši Srbi su predstavljani na televiziji kao mešavina nacionalista i glupaka (traje rat, a oni učestvuju na koncertima na otvorenom umesto da rade nešto pametno). Dobri su kosovski Albanci - koje Srbi ubijaju i proteruju sa ognjišta - a i NATO države koje im pomažu organizujući logore za izbeglice $(. . .)^{6 ،}$. $^{80}$

Slika tragedije albanskog življa dominirala je u predstavama Poljaka o ratu. Znatno ređe se u njima pojavljivala tema bombardovanja i njegovih posledica, ${ }^{81}$ mada je zahvaljujući poljskim dopisnicima javno mnjenje moglo u izvesnoj meri da

${ }^{74}$ Lech Wałęsa, „Teraz o czasie“, Wprost, br. 19, (1999).
75 Isto.
${ }^{76}$ Lech Wałęsa, „Pokój i przepaść“, Wprost, br. 27, (1999).
${ }^{77}$ Henryk Suchar, „Kraina śmierci“, Wprost, br. 15, (1999); Piotr Nowina-Konopka, „Ludzienic“, Wprost, br. 15, (1999); Maria Graczyk, Piotr Cirin, „Test dla zachodu“, Wprost, br. 19, (1999); Piotr Nowina-Konopka, „Dziewięćset drugi tysiąc“, Wprost, br. 22, (1999); Artur Górski, „Ciesz się, że żyjesz“, Polityka, br. 15, (1999); Witold Pawłowski, Artur Górski, „Ile Albanii?“, Polityka, br. 16, (1999); Witold Pawłowski, „Pożytki z piechoty”, Polityka, br. 17, (1999).

${ }^{78}$ Ł. Szurmiński, Mechanizmy propagandy..., 243.

${ }^{79}$ M. Waldenberg, Rozbicie Jugostawii..., 300.

${ }^{80}$ Tomasz Raczek, „Do przyjaciół Serbów”, Wprost, br. 16, (1999).

${ }^{81}$ „Kosowo - wojna w mediach i w opinii publicznej“, http://tnsglobal. pl/archiv_files/06899.pdf (pristupljeno 5. 11. 2016). 
upozna svakodnevni život u bombardovanim područjima Jugoslavije. Vesti novinara koji su se nalazili na mestu događanja nisu uvek bile precizne i kasnije su ispravljane (između ostalog, veličina gubitaka), ali su oni ipak uspeli da prikupe mnoga svedočanstva predstavnika politike, nauke, kulture i tzv. običnih ljudi. Brojne informacije je, između ostalog, preneo Rišard Bilski, dopisnik Žečpospolite. ${ }^{82}$

Primećene su tri vrste reakcije stanovnika Jugoslavije: panika, trud da se očuva privid svakodnevice $i$,nacionalna euforija““. ${ }^{83}$ Više puta je naglašavano da su vazdušni napadi doprineli jačanju Miloševićeve pozicije među Srbima. Valeri Amjel piše: „Greške NATO-a postale su efikasniji motor Miloševićevih uspeha nego njegova 'tiranija"“. ${ }^{84} \mathrm{O}$ životu u prestonici za vreme bombardovanja razgovarao je Rišard Bilski sa Biserkom Rajčić, prevodiocem poljske književnosti na srpski jezik, čiji je Dnevnik - svedočanstvo drame stanovnika Jugoslavije - u Poljsku stigao u obliku rukopisa nekoliko meseci posle rata. ${ }^{85}$

Četrdeset dana u bombardovanoj prestonici proveo je Robert Kalinovski, koji jedan od svojih tekstova počinje rečima: „Neko ko je posetio Beograd pre NATO bombardovanja danas će sa teškoćom prepoznati glavnu ulicu tog grada nazvanu imenom kneza Miloša“. Novinar opisuje razoren grad i skreće pažnju na promene u mentalitetu njegovih stanovnika: „Kada sam se dan pre početka napada našao u Beogradu, svi su verovali u čudo. Bili su uvereni da će bombardovanje nekako biti izbegnuto. Posle se pojavio strah (...). Posle nekoliko dana svetla više nisu gašena, a strah - barem na neko vreme - ustupio je mesto antinatovskim raspoloženjima (...). Ulice su se ponovo ispunile. Svakodnevni koncerti kod spomenika knezu Mihailu, manifestacije jedinstva i protesti protiv bombardovanja kanalisali su strah i nesigurnost. Sa bine su odjekivale lepe jugoslovenske melodije, a na jakni svakog Beograđanina se morala naći značka s natpisom ,Target“. - Svi smo potencijalni ciljevi naglašavali su stanovnici glavnog grada Jugoslavije. - Ja ne podržavam političke stavove Miloševića, ali sada sam s njim, jer je i on Srbin - rekao mi je, nadvikujući muziku, tridesetpetogodišnji Nenad. Drugi su ponavljali to isto. Ipak, patriotski zanos slabi iz dana u dan, iz nedelje u nedelju. Nema benzina i cigareta. Redovi pred kioscima za duvan, čija je prodaja ograničena, sve su duži. Hrane ima dovoljno, ali brzo mogu iskrsnuti problemi s njenim transportom. Raste zamor, a posledice bombardovanja se mogu videti sopstvenim očima“. ${ }^{86}$ Cenjeno je opredeljenje stanovnika prestonice koji su se okupljali na mostovima i stvarajući žive zidove pokušavali da ne dopuste uništavanje poslednjih prelaza preko reke.

Pojedini publicisti su sa gorkom ironijom pisali o tome da je deo Srba počeo da tretira Poljake kao agresore. Ukazivano je na uništenu fasadu poljske ambasade u

${ }^{82}$ M. Waldenberg, Rozbicie Jugostawii, 34-35.

${ }^{83}$ Dorota Nowakowska, „Łzy na moście Branka“, Gazeta Wyborcza, br. 87, (1999); Milena Dragiczević Szeszić, „Euforia i trudny spokój“, Gazeta Wyborcza, br. 81, (1999).

${ }^{84}$ Walery Amiel, „Leczenie bombami“, Wprost, br. 19, (1999).

${ }^{85}$ Ryszard Bilski, Kocioł bałkański (Warszawa: Bertelsmann Media, 2000), 393-395; Biserka Rajcic, „Dziennik serbski“, Polityka, br. 38, (1999).

${ }^{86}$ Robert Kalinowski, „Życie pod bombami“, Wprost, br. 21, (1999); P. Kowalczyk, P. Reszka, „Złodzieje traktorów“, Rzeczpospolita, br. 126 (1999); R. Bilski, „Najdziwniejsze więzienie Europy“, Rzeczpospolita, br. 39 (1999). 
Beogradu, razbijene prozore $\mathrm{i}$ iscrtane kukaste krstove, natpise „Ubice“, „NATO sluge“"i slično. ${ }^{87}$

Najviše potresnih izveštaja iz bombardovane prestonice Jugoslavije, a sporadično i sa drugih mesta, prenosile su novine Tribuna. U gotovo svakom izdanju izlazili su dopisi Ježija Hernjika i Eve Rosolak. O jugoslovenskim temama su još pisali Januš Rolicki, Kristina Šelestovska, Eugeniuš Jamula, Zigmunt Slomkovski. U člancima je prikazivana drama stanovnika, objavljivane fotografije ranjene dece u bolnicama, informacije o žrtvama među izbeglicama koje su se vraćale na Kosovo a koje je vazduhoplovstvo NATO-a greškom bombardovalo, pisano je o uništavanju infrastrukture, vodovodne mreže, elektrana, o ,tehničkim greškama“ i drugo. Pri tome je primećeno da je „objektivno komentarisanje onoga što se dešava u zemlji [tj. Poljskoj] nepoželjno“. 88 Novine su štampale članke poznatih publicista iz drugih listova čije redakcije nisu htele da objavljuju tekstove koji su se protivili bombardovanju civilnih ciljeva u Jugoslaviji, npr. Ludvika Stome koji se demonstrativno odrekao honorara u korist srpske dece siročadi. ${ }^{89}$

\section{Rat NATO-Jugoslavija i bezbednost Poljske, Evrope i sveta}

Situacija na Balkanu budila je u Poljacima strahovanja za bezbednost Evrope i sveta. Neposredno po otpočinjanju intervencije NATO-a - kako je proisticalo iz sondiranja javnog mnjenja - nije bilo isključeno ni izbijanje svetskog rata. Vladalo je interesovanje za problem Kosova u evropskoj politici, uzimajući u obzir reakciju Crne Gore i zemalja koje se graniče sa Jugoslavijom. Praćene su informacije o stavu Evropske unije u vezi sa NATO bombardovanjem Jugoslavije, ulozi EU u rasplitanju „kosovskog gordijevog čvora“ i dugoročnoj strategiji za Balkan. Po mišljenju brojnih posmatrača, Miloševićev režim i vojno angažovanje SAD ,paradoksalno“ su ubrzali proces integracije Evrope. ${ }^{90}$ Rat u Jugoslaviji je istovremeno za publiciste bio prilika da ukažu na slabosti evropskog sistema vojne bezbednosti. Ježi Surdikovski je pisao: „Intervencija NATO-a na Balkanu je pokazala vojno ništavilo Evrope. Izgradivši države blagostanja sa inertnim i birokratizovanim privredama, Nemci, Francuzi, Englezi i Italijani hoće da ih brani Amerika uz što manji sopstveni udeo“". 91 Mnoge Poljake je uznemiravala mogućnost da konflikt ugrozi bezbednost Poljske. Prilikom pristupanja Poljske NATO-u 12. marta 1999, istican je značaj tog događaja za pobo-

${ }^{87}$ J. Gadzinowski, „Zaciskając wybite zęby“, Nie, br. 21 (27. 5. 1999).

${ }_{88}^{88}$ „Nadal nie widać wyjścia“, Trybuna, br. 88 (15. 5. 1999).

${ }^{89}$ Trybuna, br. 94, (22. 4. 1999).

90 Jacek Potocki, „Małżeństwo z konieczności. Rozmowa z Milo Djukanoviciem, prezydentem Republiki Czarnogóry”, Wprost, br. 27, (1999); Jacek Potocki, „Plan bałkański. Rozmowa z ANDREI G. PLESU, ministrem spraw zagranicznych Rumunii“, Wprost, br. 22, (1999); Andrzej Szoszkiewicz, „Bałkańska lekcja. Rozmowa z Günterem Verheugenem, sekretarzem stanu w Ministerstwie Spraw Zagranicznych RFN odpowiedzialnym za politykę europejską", Wprost, br. 24, (1999); Jacek Pałasiński, „Europejska solidarność, Rozmowa z Emmą Bonino, komisarzem europejskim, kandydatką na stanowisko szefa ONZ-owskiej Agencji ds. Odbudowy Kosowa“, Wprost, br. 24, (1999); Piotr Cywiński, „Europa kontra Milosević“, Wprost, br. 24, (1999); Piotr Gabryel, „Nowy Stary Kontynent“, Wprost, br. 25, (1999).

${ }^{91}$ Jerzy Surdykowski, „Czas łotra“, Wprost, br. 19, (1999). 
ljšanje njene bezbednosti. Rat na Balkanu je, međutim, podstakao razmišljanja o opasnostima koje su proizlazile iz njegovog izbijanja. Strahovalo se od terorističkih napada, nadiranja ilegalnih imigranata $\mathrm{i}$ aktivnosti međunarodnih kriminalnih grupa. ${ }^{92} \mathrm{Sa}$,nemirom“ je posmatrana reakcija Moskve koja je branila ,slovensku pravoslavnu braću“93 „Kako će se poneti danas teško predvidljiva Rusija?“, pitao se Andžej Novosad na stranicama Politike. ${ }^{94}$ Prema publicistima Nje vazdušni napad na Srbiju ponižavao je Rusiju, što je jedino jačalo nacionalističko-imperijalističke snage $\mathrm{u}$ toj državi. U rastućem podređivanju jednoj velikoj sili sagledavana je opasnost za dotadašnju relativnu ravnotežu snaga u svetu. ${ }^{95}$ Drugi list levice, Điš, u uredničkom komentaru je ukazivao na rizik vezan za kršenje Povelje OUN (napad na suverenu zemlju bez objave rata), uzurpiranje od strane NATO-a ovlašćenja svetske vlade, suda i policije, a čak i pokušaj legalizacije terora kao metode vođenja rata. „Stari poredak će biti srušen. Novi nije nastao“".96

Jedan feljton Leha Falandiša izražava za mnoge Poljake tipičnu reakciju na rat u Jugoslaviji: „Šta će biti kada Rusija stupi u akciju? Da li postoji rizik da će hteti da kazni novopečene članove pakta?“.97 U tom kontekstu je često razmatrana cena članstva Poljske u NATO-u. Mada se podrška učešću Poljske u Paktu nije smanjila, stav prema prisustvu poljskih vojnika na područjima obuhvaćenim konfliktima bio je veoma raznolik. Većina Poljaka je odobravala njihovo prisustvo u Jugoslaviji, ,ali samo za održavanje reda i mira posle okončanja oružanog konflikta“9 98 Apel protiv učešća poljskih vojnika u vojnoj operaciji protiv Jugoslavije predsedniku Aleksandru Kvašnjevskom podnela je grupa pravoslavaca koji su smatrali da učešće Poljske u operaciji NATO-a istorija može da osudi slično kao učešće u intervenciji u Čehoslovačkoj 1968. u okviru Varšavskog sporazuma. ${ }^{99}$ Nezavisno od raznolikih stavova poljskog javnog mnjenja, na osnovu sporazuma između NATO-a i Jugoslovenske armije 10. juna 1999, posle 78 dana, obustavljena su bombardovanja i gotovo istovremeno na Kosovo su ušle snage misije Kosovo Force (KFOR). Poljska je među prvim državama donela odluku o slanju vojnika u tu misiju. Poljska jedinica, koja je brojala 800 vojnika, nalazila se u sastavu Višenacionalne brigade Istok u tzv. američkom sektoru. ${ }^{100}$

Odnos prema NATO bombardovanju Jugoslavije u Poljskoj nije bio jednoznačan. Dominantno je bilo odobravanje odluka Pakta kome je Poljska upravo bila pristupila, ali se u izjavama brojnih političara i publicista pojavilo dosta pitanja i primedbi. Suprotno drugim evropskim zemljama nisu organizovani protesti ni mitinzi podr-

92 Janusz Tomaszewski, „Echa wojny“, Wprost, br. 14, (1999).

93 Jarosław Giziński, ,Wojna o pokój“, Wprost, br. 14, (1999). O reagovanjima Rusije na rat na Balkanu videti i: M. Tryc-Ostrowska, „Moskwa nie rezygnuje z mediacji“, Rzeczpospolita, br. 111, (1999); P. Jendroszczyk, „Moskwa wysyła okręty w rejon wojny“, Rzeczpospolita, br. 77, (1999).

${ }_{94}$ Andrzej Nowosad, „Bałkańskie domino“, Polityka, br. 15, (1999).

95 „Odłamki lecą na nas“, Nie, br. 13, (1. 4. 1999).

${ }^{96}{ }^{\circ}$ Dziś, br. 5, (maj 1999).

${ }_{97}^{97}$ Lech Falandysz, „Myśl o Rosji“, Wprost, br. 15, (1999).

98 „NATO - Jugosławia: Polacy o konflikcie zbrojnym“, http://tnsglobal. pl/archiv_files/04899.pdf (pristupljeno 5. 11. 2016).

${ }_{99}$ J. S. Mac, A. Bogusz, op. cit.

${ }^{100}$ A. Orzelska, Polityka zagraniczna, 237-238. 
ške, a na to je u izvesnoj meri uticao mali broj imigranata iz Srbije i Albanije, kao i tradicionalno proameričko raspoloženje. Jedini aktivan protest je bila piketa pred ambasadom SAD u cilju skretanja pažnje da akcija NATO-a povećava podršku Miloševiću i nanosi štete civilnom stanovništvu. ${ }^{101}$

Napad NATO-a na Jugoslaviju izazvao je brojne refleksije u Poljskoj i - neretko - emotivne reakcije. Poljsko javno mnjenje se podelilo na one koji su osuđivali postupke režima u Jugoslaviji i realizaciju Miloševićevog programa etničkog čišćenja i na one koji su dovodili u sumnju opravdanost vojne intervencije na Balkanu u kojoj, pre svega, strada civilno stanovništvo. Poljaci su ispoljavali solidarnost sa izbeglicama sa Kosova, kao i sa Srbima, trudeći se da naprave razliku između drame jugoslovenskog društva i grehova vlasti. „Ne krivimo Srbe, jer bolest može da padne na svakog, krivimo bolesnu diktaturu u koju se preobrazio komunizam“, isticao je sociolog Jacek Kurčevski. ${ }^{102}$ Prateći egzodus Albanaca sa Kosova, u Poljskoj nisu zaboravljene srpske izbeglice iz Hrvatske. Tom prilikom se često pozivalo na iskustva Poljaka iz vremena rata. Evocirana su sećanja na naklonost i solidarnost koju su narodi Jugoslavije tada pokazali prema Poljacima.

U Poljskoj su još živi sećanja i refleksije na događaje koji su se odigrali 1999. u Jugoslaviji. Autori brojnih naučnih radova izvršili su temeljnu analizu uzroka srpsko-albanskog konflikta. Tokom vremena postajale su sve brojnije kritike odluke NATO-a o upotrebi sile prema Srbiji, a rastao je i broj publikacija koje pokazuju tragične posledice bombardovanja uz naglašavanje humanitarnih, pravnih, ekonomskih i ekoloških aspekata. U znatnom broju su se pojavile ocene da je akcija na Kosovu predstavljana jednostrano, uz upotrebu zvaničnih antisrpskih informacija koje je davao NATO. Takođe, znatno su produbljena gledišta autora koji su bili naklonjeni srpskoj strani, kao i grupa i listova koji nisu bili tako uticajni.

\section{IZVORI I LITERATURA}

- Dziś (1999)

- Gazeta Pomorska (1999)

- Gazeta Wyborcza (1999)

- Forum (1999)

- Nie (1999)

- Polityka (1999)

- Przeglad Tygodniowy

- Rzeczpospolita (1999)

- Trybuna (1999)

- Tygodnik Solidarność (1999)

- Wprost (1999)

102 Jacek Kurczewski, „Wojna i bazar“, Wprost, br. 16, (18. 4. 1999). 
- Biegański, Przemysław. „Współpraca miast partnerskich na przykładzie Bydgoszczy i Kragujevaca“. U: Polska i Jugosławia w stosunkach międzynarodowych po II wojnie światowej, Zbornik radova. Urednici Momčilo Pavlović, Andrzej Zaćmiński, 371-384. Bydgoszcz: Wydawnictwo Uniwersytetu Kazimierza Wielkiego, 2014.

- Bilski, Ryszard. Kociot bałkański. Warszawa: Bertelsmann Media, 2000.

- Czubiński, Antoni. Historia powszechna XX wieku. Poznań: Wydawnictwo Poznańskie, 2003.

- Gibas-Krzak, Danuta. Serbsko-albański konflikt o Kosowo w XX wieku. Uwa-runkowania-przebieg - konsekwencje. Toruń: Wydawnictwo Adam Marszałek, 2009.

- Jureńczyk, Łukasz. Polska w Sojuszu Pólnocnoatlantyckim. Wojsko Polskie w operacjach reagowania kryzysowego NATO. Bydgoszcz: Wydawnictwo Uniwersytetu Kazimierza Wielkiego, 2016.

- Kubiak, Krzysztof. „Poheroiczny Zachód wobec wyzwań militarnych pierwszych dekad XXI wieku“. U: Czynnik wojskowy w środowisku międzynarodowym na przełomie XX i XXI wieku, Zbornik radova. Urednici Łukasz Jureńczyk, Sławomir Sadowski, Marcin Jastrzębski, Jan Waskan, 15-33. Bydgoszcz: Wydawnictwo Uniwersytetu Kazimierza Wielkiego, 2016.

- Kuczyński, Maciej. Krwawiąca Europa. Konflikty zbrojne i punkty zapalne w latach 1990-2000. Tto historyczne i stan obecny. Warszawa: Dom Wydawniczy Bellona, 2001.

- Orzelska, Agnieszka. Polityka zagraniczna Polski wobec wybranych kwestii spornych w stosunkach transatlantyckich (1989-2004). Warszawa: Instytut Studiów Politycznych PAN, 2011.

- Partie i koalicje polityczne III Rzeczypospolitej. Ur: Paszkiewicz, Krystyna. Wrocław: Wydawnictwo Uniwersytetu Wrocławskiego, 2000.

- Szurmiński, Łukasz. Mechanizmy propagandy. Wizerunek konfliktu kosowskiego w publicystyce. Warszawa: Aspra, 2008.

-Waldenberg, Marek. Rozbicie Jugostawii. Jugostowiańskie lustro międzynarodowej polityki. Warszawa: Wydawnictwo Naukowe SCHOLAR, 2005.

- Kryzys w Kosowie - Decyzja NATO - Konferencja prasowa Prezydenta RP. http://www.prezydent.pl/aleksandra-kwasniewskiego/aktualnosci/rok-2000-istarsze/art,158,729,kryzys-w-kosowie-decyzja-nato-konferencja-prasowaprezydenta-rp. html (pristupljeno 9. 10. 2016).

- Odpowiedź Ministra Spraw Zagranicznych RP Bronisława Geremka na oświadczenie senatora Zbigniewa Gołąbka, złożone na 33. posiedzeniu Senatu (,Diariusz Senatu RP“ nr 35). http://ww2.senat. pl/k4/dok/diar/39/3906.htm (pristupljeno 17. 10. 2016).

- Opinie o sytuacji w Kosowie po zaprzestaniu bombardowań. Komunikat z badań, Warszawa, lipiec '99. http://www.cbos. pl/SPISKOM. POL/1999/K_105_99.PDF (pristupljeno 17. 10. 2016). 
- Polacy o interwencji NATO w Jugosławii. Komunikat $\mathrm{z}$ badań. Warszawa, kwiecień' 99. http://www.cbos. pl/SPISKOM. POL/1999/K_053_99.PDF, (pristupljeno 17. 10. 2016).

- Sejm Rzeczypospolitej Polskiej. 3 kadencja, 47 posiedzenie, 1 dzień (8. 4. 1999). 4 punkt porządku dziennego: Informacja rządu o podstawowych kierunkach polityki zagranicznej Polski. Poseł Piotr Ikonowicz. http://orka2.sejm.gov.pl/Debata3.nsf/main/2FCC18CF, (pristupljeno 9. 10. 2016).

- http://archiwum.polityka.pl

- http://archiwum.rp.pl

- http://www.archiwum.wyborcza.pl

- https://www.wprost.pl/tygodnik/archiwum

Zdzislaw Biegański

Joanna Szczutkowska

\section{POLISH PUBLIC OPINION TOWARD 1999 BOMBING OF YUGOSLAVIA}

\section{Summary}

The decision of the North Atlantic Treaty Organization (NATO) to use armed force to end the Kosovo crisis has caused much emotion and controversy in Poland. There was much public interest in the Balkans during the 1999 NATO bombing. Polish support for NATO intervention was high, but the extension of the bombing had resulted in a decrease in the percentage of its supporters. Half of the Poles approved the action, mainly those with right-wing or center-right views. Slightly less were opposed. The left-wing followers did not generally support the intervention. The events in the Balkans were regularly followed in Poland. The possible scenarios for the Kosovo situation, as well as the consequences of the war were considered, both in the context of humanitarian crisis and of Yugoslav history and identity. NATO's war against Yugoslavia has become the subject of numerous Polish publications. The media presented as different opinions on the NATO's intervention as political forces. Some of the titles were supportive (eg. „Gazeta Wyborcza“) and some were extremely critical. Among the opponents to the intervention were the titles closely associated with radical political groups, from both left and right of the political spectrum: „,Trybuna“, „NIE“, „Dziś“”, „Myśl Polska“, „Nasza Polska“ oraz „Nasz Dziennik". Only a few managed to maintain a balanced attitude towards the activities of the Alliance in Balkans (eg. „Polityka“). Remembrance and reflection on the events that happened in 1999 in Yugoslavia are kept alive in Poland.

KEYWORDS: Poland, Yugoslavia, NATO, media, Kosovo 


\title{
ÖFFENTLICHE MEINUNG ZUR BOMBARDIERUNG VON JUGOSLAWIEN IM JAHRE 1999
}

\begin{abstract}
Zusammenfassung
Die Entscheidung der Nordatlantikpakt-Organisation (NATO), bewaffnete Streitkräfte zur Beendigung der Kosowo-Krise zu verwenden, rief in Polen viele Emotionen und Kontroversen hervor. Das Interesse der öffentlichen Meinung an der Situation auf dem Balkan während der Luftangriffe der NATO im Jahr 1999 war in Polen bedeutend. Der Konflikt erhielt die Aufmerksamkeit der eindeutigen Mehrheit der Polen. Die Befürwortung der Intervention durch die NATO war in der polnischen Bevölkerung hoch, jedoch sank der Prozentsatz der Fürsprecher im Laufe der Luftangriffe. Die Hälfte der Polen drückte ihre Zustimmung für die Aktion aus und diese waren meist rechts und zentral-rechts orientierte Personen. Nicht viel weniger gab es an Gegenmeinungen. Die Intervention der Allianz wurde insbesondere von der links orientierten Bevölkerung abgelehnt. Die Ereignisse auf dem Balkan wurden durchgehend in den Medien verfolgt. Dabei wurden mögliche Szenarien der Konfliktlösung und die Folgen des Kosovokrieges nicht nur im Kontext der humanitären Krise, sondern auch im Kontext der jugoslawischen Geschichte und ihrer Identitätskrise betrachtet. Die bewaffnete Intervention der NATO gegen Jugoslawien war Gegenstand vieler polnischer Publikationen. Die Presse, ähnlich wie die Parteien aus der Politik, zeigte unterschiedliche Meinungen zum Thema der Bündnis-Intervention. Einige Schlagzeilen unterstützten diese (z.B. die Presse „Gazeta Wyborcza”), hingegen andere Pressestimmen zeigten sich sehr kritisch. Unter den Gegnern gab es Pressetitel, die weitestgehend die Zugehörigkeit zu radikal-politischen Gruppierungen anklingen ließen, dieses sowohl von Seiten der linken als auch rechten politischen Szene: „Trybuna“, „NIE“, „Dziś““, „Myśl Polska“, „Nasza Polska“ sowie „Nasz Dziennik“. Nur wenige Titel bemühten sich eine besonnene Haltung gegenüber den Handlungen des Büdnisses auf dem Balkan zu zeigen (z.B. „Polityka”). Im Presseartikel wurden hier ebenfalls Beispiele für lokal-polnische Iniziativ-Hilfsorganisationen zur Unterstützung von zerstörten Orten in Jugoslawien aufgezählt. Die Erinnerung und Reflektion der Ereignisse, welche im Jahr 1999 in Jugoslawien stattfanden, sind derweil in Polen lebendig geblieben.
\end{abstract}

SCHLÜSSELWORTER: Polen, Jugoslawien, NATO, Presse, Kosovo 